\title{
Characteristics of the Flora and Woody Vegetation of Agroforestry Parks in the District of Kataba 1 (Bignona, Lower Casamance)
}

\author{
Baboucar Sane ${ }^{1}$, Ismaïla Coly ${ }^{1 *}$, Aliou Badji ${ }^{1}$, Tahirou Charles Diatta ${ }^{1}$, \\ Arfang Ousmane Kémo Goudiaby', Daouda Ngom² \\ ${ }^{1}$ Agroforestry and Ecology Laboratory, Department of Agroforestry, Assane SECK University, Ziguinchor, Senegal \\ ${ }^{2}$ Plant Ecology Laboratory, Department of Plant Biology, Cheikh Anta DIOP University, Dakar, Senegal \\ Email: *icoly@univ-zig.sn
}

How to cite this paper: Sane, B., Coly, I., Badji, A., Diatta, T.C., Goudiaby, A.O.K. and Ngom, D. (2021) Characteristics of the Flora and Woody Vegetation of Agroforestry Parks in the District of Kataba 1 (Bignona, Lower Casamance). Open Journal of Ecology, 11, 741-757.

https://doi.org/10.4236/oje.2021.1111046

Received: October 2, 2021

Accepted: November 6, 2021

Published: November 9, 2021

Copyright $\odot 2021$ by author(s) and Scientific Research Publishing Inc. This work is licensed under the Creative Commons Attribution International License (CC BY 4.0).

http://creativecommons.org/licenses/by/4.0/

Open Access

\begin{abstract}
Like several Sahelian countries, Senegal is facing a strong degradation of woody and arable resources. This is due to the development of certain inappropriate agricultural practices. To mitigate this situation, the populations tend to preserve and maintain certain woody species of interest in the fields, thus constituting agroforestry parks. Thus, the objective of this study was to contribute to a better understanding of the characteristics of woody vegetation in agroforestry parks in the department of Bignona. To this end, a plot of $2500 \mathrm{~m}^{2}(50 \mathrm{~m} \times 50 \mathrm{~m})$ was installed in the fields of each farmer selected in a sample of 99 farm managers distributed in the three communes (Djinaky, Katabal and Kafountine) of the Katabal district, for a total of 99 plots installed. A total of seventy-three (73) species divided into fifty-five (55) genera and twenty-eight (27) botanical families were inventoried. In the agroforestry parks of the Kataba 1 district, the density of woody vegetation is 56.12 individuals/ha, the cover rate is $27.9 \%$ and the basal area is $5.9 \mathrm{~m}^{2} / \mathrm{ha}$. The vertical structure of the woody vegetation is characterized by a predominance of individuals between 2 and $4 \mathrm{~m}$ in height (48.07\%). As for the horizontal structure, it is characterized by a predominance of individuals of diameter between 5 and $20 \mathrm{~cm}(39.19 \%)$. These results obtained will serve as a source of information for better management of these agroforestry parks by the populations.
\end{abstract}

\section{Keywords}

Agroforestry Parks, Flora, Woody Vegetation, Kataba 1

\section{Introduction}

In the semi-arid and sub-humid zones of West Africa, farmers have been im- 
plementing a traditional land use system known as "agroforestry parks" for generations [1]. It is characterized by the deliberate maintenance of trees scattered on cultivated land or on recent fallow land [2] [3]. These trees are an integral part of the system and provide food, fuel, fodder, medicinal substances, building materials and marketable products. In addition to these services, these trees also contribute to the maintenance of soil fertility, water conservation and environmental protection. Through species selection, farmers have deliberately adapted tree production to their specific needs on their land [1].

The natural region of Casamance, in Senegal, has the greatest diversity of wood resources in the country [4]. These ecosystems generate very important foreign exchange and environmental services, thus contributing to cultural and socio-economic development worldwide. Indeed, according to [5], forestry remains a factor of economic development and contributes to $2.7 \%$ of the GDP in ten major tropical producing countries. However, these important ecosystems are now threatened by climatic hazards and strong anthropic pressure. The latter results in the uncontrolled exploitation of certain species of interest such as those producing quality timber. These species are often exploited fraudulently without any respect for management principles [6]. Indeed, species such as Pterocarpus erinaceus are currently threatened in all forest areas and agroforestry parks in the Sahelo-Sudanian and Sudanian zone [7]. Therefore, an assessment of the current status of these ecosystems appears to be imperative. It is in this perspective that this study proposes to establish the floristic and structural characteristics of the woody vegetation of these agrarian systems. The aim of this study is to establish the floristic and structural characteristics of the woody vegetation of these agrarian systems in order to have a database for more rational management of these ecosystems.

\section{Material and Methods}

\subsection{Presentation of the Study Area}

The district of Katabal belongs to the department of Bignona and the region of Ziguinchor. It consists of four communes, three of which are rural (Kafountine, Djinaky and Kataba 1) and one urban (Diouloulou). It is bordered to the east by the Sindian district, to the south by the Oussouye department and the Tendouck district, to the west by the Atlantic Ocean and to the north by the Gambia (Figure 1).

From a climatic standpoint, the Katabal district belongs to the Lower Casamance climatic zone, which has a coastal South Sudanese type of climate marked by the existence of two seasons: a dry season and a rainy season. The lower Casamance is characterized by rainfall that is higher than $1000 \mathrm{~mm}$ everywhere [8]. The average annual rainfall over the 1980-2018 series is 1302.04 mm (Figure 2) [9].

The nature of the soils in Lower Casamance is a function of the toposequence [10]. Three types of soil are encountered: hydro morphic soils exploited for rice 


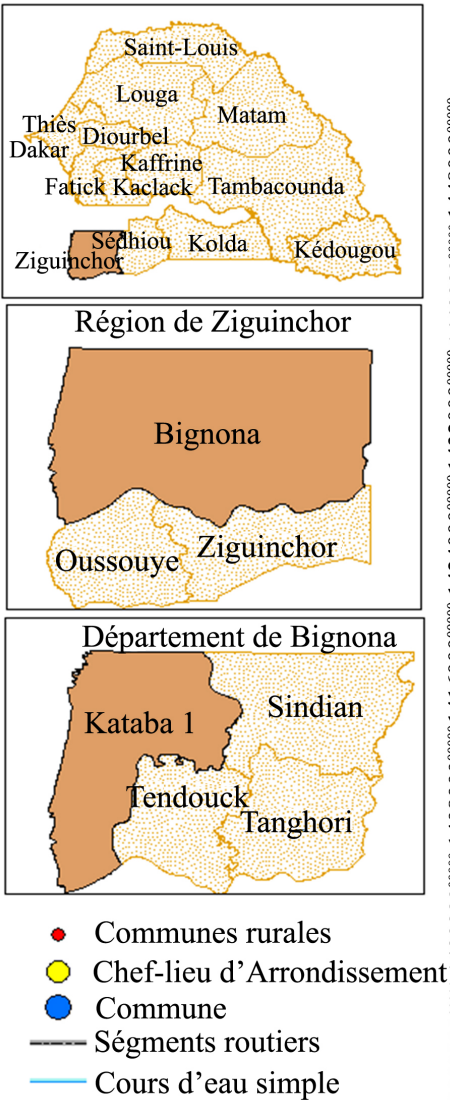

$300000^{00000} 308000^{00000} 316000^{00000} 324000^{00000} 332000^{00000} 340000^{00000} 348000^{00000} 356000^{00000} 364000^{00000}$

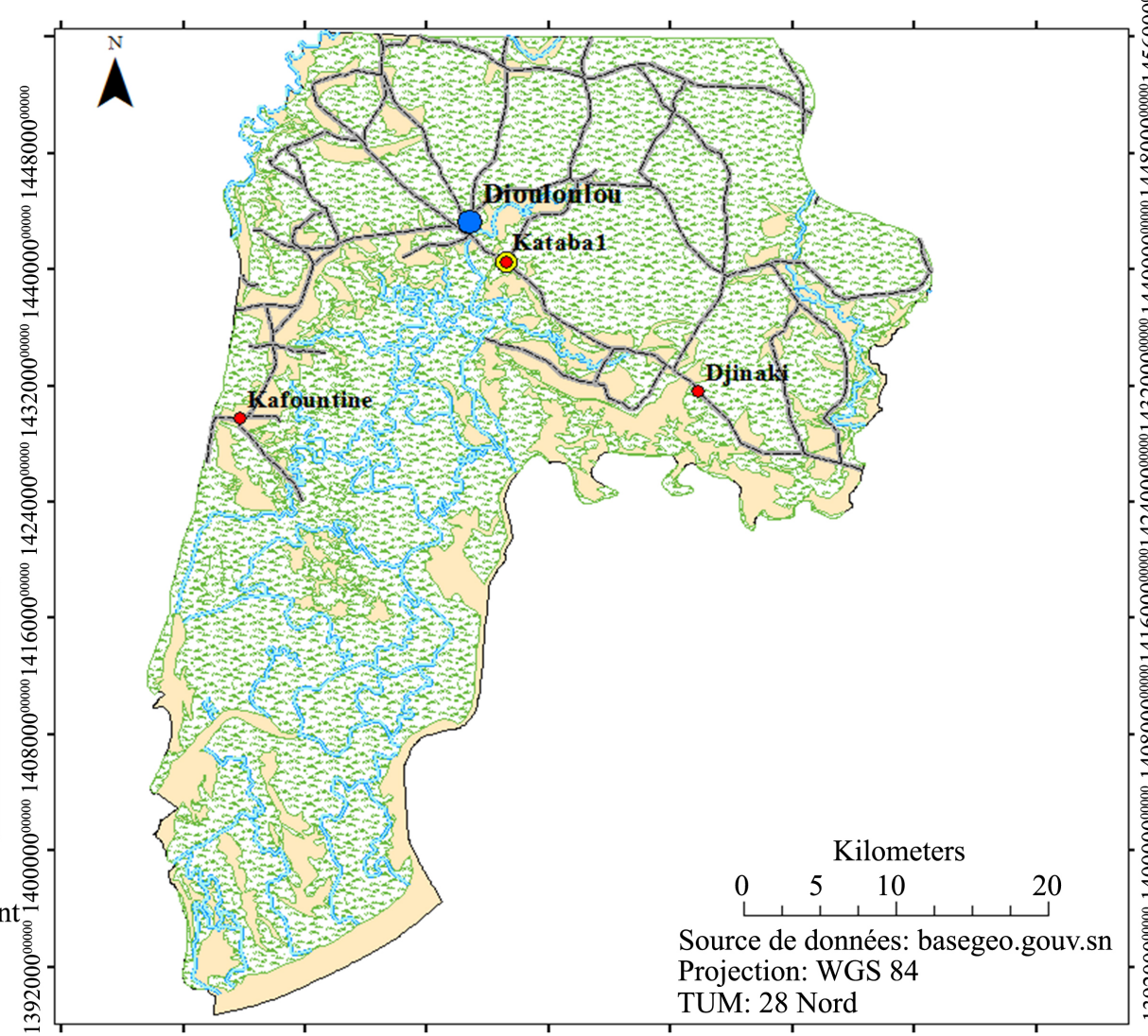

$300000^{00000} 308000^{00000} 316000^{00000} 324000^{00000} 332000^{000000} 340000^{00000} 348000^{00000} 356000^{00000} 364000^{000000}$

Figure 1. Location map of the Katabal district.

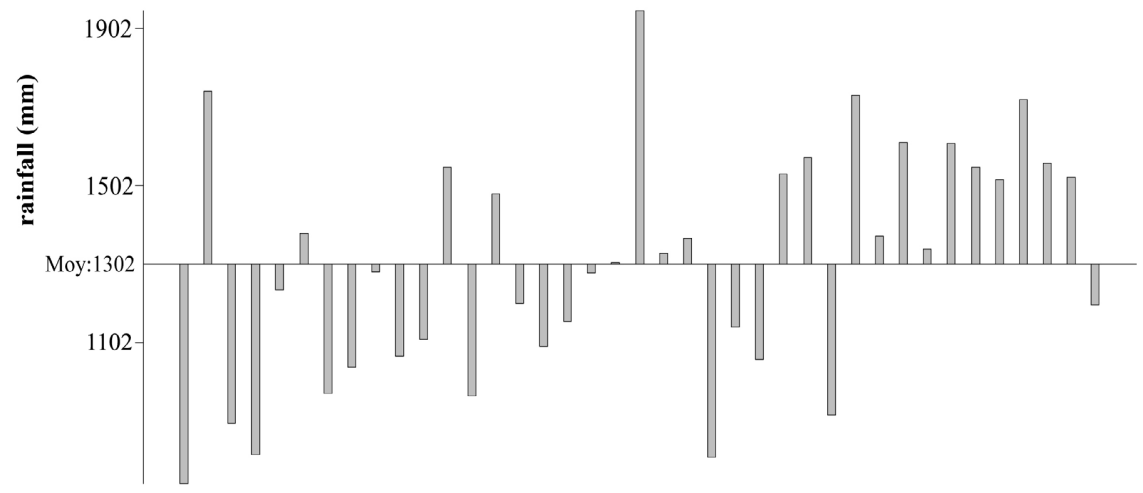

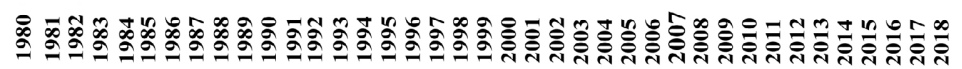

years

Figure 2. Variation in mean annual rainfall $(\mathrm{mm})$ for the 1988 -2018 series recorded at the meteorological station in the Ziguinchor region [9].

and market gardening; acid sulfate soils in the lower part of the basin, tropical ferruginous soils and ferralitic soils exploited for rainfed crops on the plateaus and terraces forming the watersheds [11]. 


\subsection{Vegetation Surveys}

Stratified sampling was carried out in the agroforestry parks of Katabal district, taking the three municipalities of the district as strata (Table 1). The criterion for choosing villages was based on geographic distribution in order to ensure a good network in each municipality. The selection criterion for farmers is whether they have a cultivated field.

Thus, 99 plots are distributed among the municipalities in proportion to their number of farms, with one plot per farm manager. The survey area is $2500 \mathrm{~m}^{2}$ as recommended by [12] for the study of woody vegetation in agroforestry systems.

In each plot, all species were inventoried and dendrometric measurements were made for each individual that reached the pre-count diameter $(5 \mathrm{~cm})$.

The dendrometric parameters measured are:

- Trunk diameter at breast height (DBH) using a forestry compass;

- The circumference of the trunk using a metric tape for individuals with a large trunk;

- Tree height using a suntoo dendrometer;

- The cross-sectional diameter of the crown (East-West and North-South) using a metric tape.

Also, an exhaustive count of all young individuals, with a diameter less than 5 $\mathrm{cm}$ was carried out to evaluate the regeneration.

\subsection{Data Processing}

The data from the vegetation surveys were entered into an EXCEL spreadsheet. The latter was used to perform the calculations and to develop graphs and tables. XLSTAT Version 2014 was used for the multivariate treatments, in particular the Principal Component Analysis (PCA).

A number of formulas were used to assess diversity and to calculate vegetation structure parameters.

Species richness is the total number of species in a given stand in a given ecosystem [13].

Frequency analysis is a method of assessing the distribution of species across surveys. The frequency $(F)$ provides information on the distribution of a species

Table 1. Number of villages and farms by commune and in the sample.

\begin{tabular}{ccccc}
\hline \multirow{2}{*}{ Municipalities } & \multicolumn{4}{c}{ Sample } \\
\cline { 2 - 5 } & $\begin{array}{c}\text { Number } \\
\text { of villages }\end{array}$ & $\begin{array}{c}\text { Number } \\
\text { of farms }\end{array}$ & $\begin{array}{c}\text { Number } \\
\text { of villages }\end{array}$ & $\begin{array}{c}\text { Number } \\
\text { of farms }\end{array}$ \\
\hline Djinaky & 25 & 201 & 3 & 5 \\
Kataba 1 & 35 & 2596 & 7 & 30 \\
Kafountine & 17 & 5755 & 5 & 64 \\
Total & $\mathbf{7 7}$ & $\mathbf{8 5 5 2}$ & $\mathbf{1 5}$ & $\mathbf{9 9}$
\end{tabular}


in a stand. It is estimated in percent (\%). It is calculated as follows:

$$
F=\frac{N_{r i}}{N_{r}} \times 100 .
$$

$F=$ frequency of occurrence, $N_{r i}=$ number of surveys where species $i$ is found, $N_{r}=$ total number of surveys.

The density is the number of individuals per unit area. It is expressed in number of individuals per hectare. The observed density $\left(D_{o b}\right)$ is obtained by dividing the total number of individuals in the sample $(N)$ by the sampled area $(S)$.

$$
D_{o b}=\frac{N}{S} \text {. }
$$

The woody cover $(C)$, is the surface covered by the projection of the tree crown in relation to the ground. It is expressed in square meters per hectare $\left(\mathrm{m}^{2} / \mathrm{ha}\right)$ and is calculated as follows:

$$
C=\sum \pi\left[\frac{d_{m h}}{2}\right]^{2} / S_{E} .
$$

$C=$ woody cover; $d_{m h}=$ average crown diameter in $\mathrm{m} ; S_{E}=$ area of the sample considered in ha.

Basal area (BA) is the area of the tree evaluated at the base of the tree trunk. It is expressed in square meters per hectare $\left(\mathrm{m}^{2} / \mathrm{ha}\right)$ and is obtained by the following formula:

$$
S_{t}=\sum \pi\left[\frac{d_{1,3}}{2}\right]^{2} / S_{E} .
$$

$d_{1,3}=$ diameter $(\mathrm{m})$ at breast height, $S_{E}=$ sample area in hectares.

The Shannon-Weaver diversity index [14] provides information on the magnitude of the number of abundant species in a given environment. It is expressed in bits.

It is given by the following formula:

$$
H^{\prime}=-\sum p_{i} \log _{2} p_{i} .
$$

$p_{i}=$ relative abundance of each species. $\log _{2}=\operatorname{logarithm}$ calculated with base 2.

$p_{i}=N_{i} / N$, where $N_{i}=$ the number of species $i ; N=$ total number of species.

The evenness index $(E)$ provides information on the distribution of species abundances in the stand. According to [15], the regularity index appears to be a more rigorous comparison term. It is between 0 and 1 . It tends towards 0 when all the individuals correspond to a single species. It is calculated as follows:

$$
E=\frac{H^{\prime}}{H_{\max }} .
$$

$H_{\max }=\log _{2} s$ avec $s=$ effectif total des espèces.

\section{Results}

\subsection{Floristic Composition}

The woody flora of the agroforestry parks of Katabal district is rich in seven- 
ty-three (73) species distributed in fifty-five (55) genera and twenty-eight (28) botanical families. The most represented families are: Fabaceae (18.66\%), Moraceae (8\%) and Anacardiaceae, Caesalpiniaceae and Rutaceae with each a proportion of $6.66 \%$. These five (5) families alone represent $33.32 \%$ of the species inventoried (Table 2).

Of these 73 species, the municipality of Katabal recorded 23 species divided into 23 genera elonging to 12 families. In the commune of Djinaky, 52 species were recorded. These are divided into 41 genera belonging to 19 families. As for the commune of Kafountine, it recorded 63 species divided into 48 genera and 25 families (Table 2).

\subsection{Frequency Analysis}

The analysis of the table below shows that in the Kataba districtl the most frequent woody species in agroforestry parks are: Borassus akeassii (42.42\%), Mangifera indica (40.40\%), and Citrus sinensis (39.39\%). The lowest frequency is observed in Afzelia africana, Albizzia zigya, Allophullus africanus with a frequency of presence of $1.01 \%$ each.

At the municipality level, it appears that Mangifera indica, Combretum micranthum, and Parkia biglobosa are the most frequent species in the municipality of Djinaky with frequencies of presence of $80 \%, 80 \%$, and $60 \%$ respectively.

In the municipality of Kataba1, the most frequent species are Parkia biglobosa (60\%), Borassus akeassii (50\%) and Pterocarpus erinaceus (46.67\%).

In the commune of Kafountine, Piliostigma thonninguii, Elaeis guineensis, and Citrus sinensis are the most frequent species with respective frequencies of presence of 50\%, 45.31\%, and $42.19 \%$ (Table 3 ).

\subsection{Structural Characteristics of Woody Vegetation in Agroforestry Parks}

The average cover rate of agroforestry parks in the Katabal district is $27.9 \%$. It is higher in the municipality of Djinaky (28.49\%) and lower in that of Kafountine (13.10\%) (Table 4).

The basal area is $5.6 \mathrm{~m}^{2} / \mathrm{ha}$ in the parks of the district. It is higher in the parks of the municipality of Djinaky $\left(5.48 \mathrm{~m}^{2} / \mathrm{ha}\right)$ and lower in those of the municipality of Kafountine (2.82\%) (Table 4).

As for density, it is 56.12 individuals/ha at the scale of the parks of the district and is higher in the parks of the municipality of Katabal with 64 individuals/ha and lower in those of the municipality of Djinaky (19.2 plants/ha).

Specific diversity is highest in the parks of the municipality of Djinaky with a Shannon index of 3.38 bits and a Pielou index of 0.77 . The lowest diversity is noted in the parks of the commune of Kafountine with a Shannon index of 2.74 bits and a Pielou index of 0.53 (Table 4).

\subsection{Regeneration Rate of Agroforestry Parks}

The regeneration rate of woody vegetation in the agroforestry parks of the 
Table 2. Floristic composition of agroforestry parks in the Kataba1 district.

\begin{tabular}{|c|c|c|c|c|c|c|}
\hline \multirow[b]{2}{*}{ Families } & \multirow[b]{2}{*}{ genera } & \multirow[b]{2}{*}{ Species } & \multicolumn{4}{|c|}{ Municipalities and district } \\
\hline & & & Dji. & Kat.1 & Kaf. & $\begin{array}{c}\text { Kat.1 } \\
\text { District }\end{array}$ \\
\hline \multirow{5}{*}{ Anacardiaceae } & Anacardium & Anacardium occidentale L. & + & + & + & + \\
\hline & Lannea & Lannea acida A. Rich. & + & + & + & + \\
\hline & Lannea & Lannea velutina A. Rich. & - & - & + & + \\
\hline & Mangifera & Mangifera indica L. & + & + & + & + \\
\hline & Spondias & Spondias mombin L. & - & - & + & + \\
\hline \multirow{4}{*}{ Annonaceae } & Annona & Annona glauca Schumach. \& Thonn. & - & + & + & + \\
\hline & Annona & Annona senegalensis Pers. & + & + & + & + \\
\hline & Annona & Annona squamosa $L$. & - & - & + & + \\
\hline & Uvaria & Uvaria chamea L. & + & + & - & + \\
\hline \multirow{4}{*}{ Apocynaceae } & Calotropis & Calotropis procra (Aiton) W. T. Aiton & - & + & + & + \\
\hline & Holarrhena & Holarrhena floribunda L. & + & + & - & + \\
\hline & Landolphia & Landolphia heudolotii A. DC. & - & + & + & + \\
\hline & Saba & Saba senegalensis (A. DC.) Pichon & - & + & + & + \\
\hline \multirow{3}{*}{ Arecaceae } & Cocus & Cocus nucifera $L$. & - & - & + & + \\
\hline & Borassus & Borassus akeassii Bayton. Ouédr. \& Guinko. & + & + & + & + \\
\hline & Elaeis & Elaeis guineensis Jacq. & + & + & + & + \\
\hline Asclepiadaceae & Calotropis & Calotropis procera (Aiton) W.T.Aiton & - & + & + & + \\
\hline Bignoniaceae & Newbouldia & Newbouldia laevis (P. Beauv.) Seem & - & + & + & + \\
\hline \multirow{2}{*}{ Bombacaceae } & Adonsonia & Adonsonia digitata L. & - & - & + & + \\
\hline & Bombax & Bombax aquaticum (Aubl.) K. Schum. & - & + & + & + \\
\hline \multirow{5}{*}{ Caesalpiniaceae } & Detarium & Detarium guineensis Willd. & + & + & + & + \\
\hline & Detarium & Detarium senegalensis Gmel. & - & + & + & + \\
\hline & Dialium & Dialium guineensis Willd. & - & + & - & + \\
\hline & Piliostigma & Piliostigma reticulata (Schumach.) Milne-Redh & - & + & + & + \\
\hline & Piliostigma & Piliostigma thonninguii (Schumach.) Milne-Redh. & + & + & + & + \\
\hline Caricaceae & Carica & Carica papya $L$. & - & - & + & + \\
\hline \multirow{2}{*}{ Chrysobalanaceae } & Ceiba & Ceiba pentandra (L.) Gaertn. & - & - & + & + \\
\hline & Neocaria & Neocarya macrophylla (Sabine) Prance & - & - & + & + \\
\hline \multirow{5}{*}{ Combretaceae } & & Combretum glutinosum Perr. Ex DC. & - & + & + & + \\
\hline & Combretum & Combretum micranthum G. Don & + & + & + & + \\
\hline & & Combretum paniculatum & - & - & + & + \\
\hline & Guiera & Guiera senegalensis J. F. Gmel & - & + & + & + \\
\hline & Terminalia & Terminalia macroptera Guill. \& Perr. & + & + & + & + \\
\hline
\end{tabular}




\section{Continued}

\begin{tabular}{|c|c|c|c|c|c|c|}
\hline Icacinaceae & Icacina & Icacina senegalensis Juss & + & + & - & + \\
\hline Lamiaceae & Phloemis & Phloemis africana P. Beauv. & - & - & + & + \\
\hline Malvaceae & Cola & Cola cordifolia (Cav.) R. Br & + & + & - & + \\
\hline \multirow{2}{*}{ Meliacea } & Azadirachta & Azadirachta indica A. Juss. & + & + & + & + \\
\hline & Khaya & Khaya senegalensis (Desr.) A. Juss. & - & + & + & + \\
\hline \multirow{14}{*}{ Mimosaceae } & Afzelia & Afzelia africana Sm. \& Pers. & + & - & - & + \\
\hline & Albizia & Albizia adianthifolia W. Wight & - & + & + & + \\
\hline & Albizia & Albizia zygia (DC.) J. F. Macbr & - & + & - & + \\
\hline & Cassia & Cassia aulo DC. & - & + & - & + \\
\hline & Cassia & Cassia sieberiana DC. & + & + & + & + \\
\hline & Cordyla & Cordyla pinnata Lour. & - & - & + & + \\
\hline & Daniellia & Daniellia oliveri (Rolfe) Hutch. \& Dalziel & - & + & - & + \\
\hline & Dicrostachys & Dicrostachys cineria (L.) Wight. \& Arn. & + & + & + & + \\
\hline & Erythrina & Erythrina senegalensis $\mathrm{L}$. & - & + & + & + \\
\hline & Faidherbia & Faidherbia albida (Delile) A. Chev. & + & + & + & + \\
\hline & Parkia & Parkia biglobosa (Jacq.) R. Br. Ex G. Don & + & + & + & + \\
\hline & Prosopis & Prosopis sp & - & + & - & + \\
\hline & Prosopis & Prosopis africana (Guill. \& Perr.) Taub. & + & + & + & + \\
\hline & Pterocarpus & Pterocarpus erinaceus Poir. & - & + & + & + \\
\hline \multirow{6}{*}{ Moraceae } & Antiaris & Antiaris africana Engl. & - & + & + & + \\
\hline & Ficus & Ficus asperifolia & - & + & + & + \\
\hline & Ficus & Ficus exasperata Vahl & - & - & + & + \\
\hline & Ficus & Ficus sycomorus $\mathrm{L}$. & - & + & + & + \\
\hline & Ficus & $s p$ & - & + & + & + \\
\hline & Ficus & Ficus vogeli Miq. & - & - & + & + \\
\hline Moringaceae & Moringa & Moringa oleifera Lam. & - & - & + & + \\
\hline Myrtaceae & Psidium & Psidium guajava $L$. & - & + & - & + \\
\hline Phyllanthaceae & Margaritaria & Margaritaria discoidea (Baill.) G. L. Webster & - & - & + & + \\
\hline Rhamnacea & Ziziphus & Ziziphus mauritiana Lam. & - & - & + & + \\
\hline \multirow{2}{*}{ Rubiaceae } & Sarcocephalus & Sarcocephalus latifolia Afzel. Ex R. Br & - & + & + & + \\
\hline & Sarcocephalus & Sarcocephalus leavis Afzel. Ex R. Br & - & - & + & + \\
\hline \multirow{3}{*}{ Rutaceae } & Citrus & Citrus lemon (L.) Burm. F. & - & + & + & + \\
\hline & Citrus & Citrus reticulata L. & - & + & + & + \\
\hline & Citrus & Citrus sinensis (L.) Osbeck & - & + & + & + \\
\hline
\end{tabular}




\section{Continued}

\begin{tabular}{|c|c|c|c|c|c|c|}
\hline & Fagara & Fagara senegalensis (DC.) A. Chev. & - & + & + & + \\
\hline & Fagara & Fagara xanthoxyloides Lam. & - & - & + & + \\
\hline Sapindaceae & Allophylus & Allophulus africanus $\mathrm{P}$. Beauv. & + & - & - & + \\
\hline Simaroubaceae & Hannoa & Hannoa undulata (Guill. \& Perr) Planch. & - & + & - & + \\
\hline Ulmaceae & Celtus & Celtus integrifolia Lam. & + & - & + & + \\
\hline \multirow{2}{*}{ Verbanaceae } & Gmelina & Gmelina arborea Roxb. EX Sm. & - & + & + & + \\
\hline & Vitex & Vitex doniana Oliv. & - & - & + & + \\
\hline Total 27 & 55 & 73 & 23 & 52 & 63 & 73 \\
\hline
\end{tabular}

Legend: Kat.1 = Kataba 1; Kaf = Kafountine; Dji = Djignaky; Kat1 District = Kataba 1 District. +: presence; -: absence.

Table 3. Frequency of presence (\%) of inventoried species according to the municipalities and the district of Kataba 1.

\begin{tabular}{|c|c|c|c|c|}
\hline \multirow{2}{*}{ Species } & \multicolumn{3}{|c|}{ Municipalities } & \multirow{2}{*}{$\begin{array}{c}\text { Kataba } 1 \\
\text { District }\end{array}$} \\
\hline & Djinaky & Kataba 1 & Kafountine & \\
\hline Adansonia digitata $L$. & 0 & 0 & 3.125 & 2.02 \\
\hline Afzelia africana Sm. \& Pers. & 20 & 0 & 0 & 1.010 \\
\hline Albizzia adiantifolia W. Wight & 0 & 6.660 & 1.563 & 33.333 \\
\hline Albizzia zygia (DC.) J. F. Macbr. & 0 & 3.330 & 0 & 1.010 \\
\hline Allophullus africanus $\mathrm{P}$. Beauv & 20 & 0 & 0 & 1.010 \\
\hline Anacardium occidentale $L$. & 40 & 33.333 & 20.313 & 25.253 \\
\hline Annona glauca Schumach. \& Thonn. & 0 & 23.330 & 1.560 & 8.081 \\
\hline Annona senegalensis Pers. & 20 & 23.333 & 15.625 & 18.182 \\
\hline Annona squamosa $L$. & 0 & 0 & 6.250 & 4.040 \\
\hline Antiaris africana Engl. & 0 & 3.330 & 1.560 & 2.020 \\
\hline Azadirachta indica A. Zuss & 20 & 16.667 & 14.063 & 16.162 \\
\hline Bombax aquaticum (Aubl.) K. Schum. & 0 & 3.330 & 15.600 & 2.020 \\
\hline Borassus akeassii Bayton, Ouédraogo \& Guinko & 20 & 50 & 40.625 & 42.424 \\
\hline Calotropis procera (Aiton) W. T. Aiton & 0 & 3.330 & 23.438 & 16.162 \\
\hline Carica papya $L$. & 0 & 0 & 7.810 & 5.051 \\
\hline Cassia aulo & 0 & 3.330 & 0 & 1.010 \\
\hline Cassia sieberiana DC. & 40 & 33.333 & 6.250 & 16.162 \\
\hline Ceiba pentendra (L.) Gaertn. & 0 & 0 & 1.560 & 1.010 \\
\hline Celtis integrifolia DC. & 20 & 0 & 1.560 & 2.020 \\
\hline Citrus limon (L.) Burm. $f$ & 0 & 13.330 & 6.250 & 8.081 \\
\hline Citrus reticulata Blanco. & 0 & 6.660 & 6.250 & 6.061 \\
\hline Citrus sinensis (L.) Osbeck & 0 & 40 & 42.188 & 39.394 \\
\hline
\end{tabular}




\begin{tabular}{|c|c|c|c|c|}
\hline Cocus nucifera $L$. & 0 & 0 & 1.560 & 1.010 \\
\hline Cola cordifolia (Cav.) R. Br & 20 & 6.660 & 0 & 3.030 \\
\hline Combretum glutinosom Perr. Ex DC. & 0 & 10 & 1.560 & 4.040 \\
\hline Combretum micranthum G. Don & 80 & 23.330 & 6.250 & 13.131 \\
\hline Combretum paniculatum & 0 & 0 & 1.560 & 0 \\
\hline Cordyla pinnata Lour. & 0 & 0 & 7.813 & 5.051 \\
\hline Daniellia oliveri (Rolfe) Hutch. \& Dalziel & 0 & 6.660 & 0 & 2.020 \\
\hline Detarium guineensis Willd. & 40 & 6.660 & 3.125 & 6.061 \\
\hline Detarium senegalense Gmel. & 0 & 20 & 1.560 & 7.071 \\
\hline Dialium guineensis Willd. & 0 & 3.333 & 0 & 1.010 \\
\hline Dichrostachys cineria $L$. & 20 & 23.333 & 17.188 & 19.192 \\
\hline Elaeis guineensis Jacq. & 40 & 20 & 45.313 & 37.374 \\
\hline Erythrina senegalense $L$. & 0 & 10 & 9.375 & 9.091 \\
\hline Fagara senegalensis (DC.) A. Chev. & 0 & 6.660 & 4.680 & 5.051 \\
\hline Fagara xanthoxyloides Lam. & 0 & 0 & 1.560 & 1.010 \\
\hline Faidherbia albida (Del) A. Chev. & 20 & 13.333 & 17.188 & 16.162 \\
\hline Ficus asperfolia Miq. & 0 & 10 & 3.120 & 5.051 \\
\hline Ficus exasperata Vahl. & 0 & 0 & 4.688 & 3.030 \\
\hline Ficus niafolocarpa (Miq.) C. C. Berg & 0 & 3.330 & 7.810 & 6.061 \\
\hline Ficus sp Miq. & 0 & 6.660 & 3.120 & 4.040 \\
\hline Ficus vogeli Miq. & 0 & 0 & 7.810 & 5.051 \\
\hline Gmelina arborea Roxb. EX Sm. & 0 & 6.660 & 3.120 & 4.040 \\
\hline Guiera senegalensis Adans. Ex Juss. & 0 & 16.667 & 1.560 & 6.061 \\
\hline Hannoa undulata (Guill. \& Perr.) Planch. & 0 & 3.330 & 0 & 1.010 \\
\hline Holarrhena africana $D C$. & 20 & 3.330 & 0 & 2.020 \\
\hline Icacina senegalensis A. Juss & 20 & 40 & 37.500 & 3.374 \\
\hline Khaya senegalensis (Ders.) A. Juss. & 0 & 6.660 & 3.125 & 4.040 \\
\hline Landolphia heudeloti A. DC & 0 & 6.660 & 1.560 & 3.030 \\
\hline Lannea acida $A$. Rich. & 20 & 6.667 & 1.560 & 3.030 \\
\hline Lannea velutina $A$. Rich. & 0 & 0 & 1.560 & 1.010 \\
\hline Mangifera indica $L$. & 80 & 30 & 42.188 & 40.404 \\
\hline Margaritaria discoidea (Baill.) G. L. Webster & 0 & 0 & 1.560 & 1.010 \\
\hline Moringa oleifera Lam. & 0 & 0 & 1.560 & 1.010 \\
\hline Neocarya macrophylla (Sabine) Prance & 0 & 0 & 1.560 & 1.010 \\
\hline Newbouldia laevis (P. Beauv.) Seem & 0 & 10 & 7.813 & 8.081 \\
\hline
\end{tabular}




\begin{tabular}{|c|c|c|c|c|}
\hline Parkia biglobosa (Jacq.) Benth & 60 & 50 & 4.680 & 21.212 \\
\hline Phlomis africana $P$. Beauv. & 0 & 0 & 6.250 & 4.040 \\
\hline Piliostigma reticulate (Schumach.) Milne-Redh. & 0 & 3.330 & 3.120 & 3.030 \\
\hline Piliostigma toninguii (Schumach.) Milne-Redh. & 40 & 43.333 & 50 & 43.434 \\
\hline Prosopis Africana (Guill., Perrot et Rich.) Taub. & 20 & 30 & 4.688 & 13.131 \\
\hline Prosospis sp (Guill., Perrot et Rich.) Taub. & 0 & 3.330 & 0 & 1.010 \\
\hline Psidium goyava $L$. & 0 & 3.333 & 0 & 1.010 \\
\hline Pterocarpus erinaceus Poir. & 0 & 46.667 & 12.500 & 22.222 \\
\hline Saba senegalensis A.DC & 0 & 16.667 & 1.560 & 6.061 \\
\hline Sarcocephalus latifolia Afzel. Ex R.Br & 0 & 13.333 & 20.313 & 17.172 \\
\hline Sarcocephalus leavis Afzel. Ex R.Br & 0 & 0 & 14.063 & 9.091 \\
\hline Spondias mombin $L$. & 0 & 0 & 6.250 & 4.040 \\
\hline Terminalia macroptera Guill \& Perr. & 20 & 43.333 & 18.750 & 26.263 \\
\hline Uvaria chamae $L$. & 20 & 10 & 0 & 4.040 \\
\hline Vitex doniana Oliv. & 0 & 0 & 3.120 & 2.020 \\
\hline Zizyphus mauritiana Lam. & 0 & 0 & 3.125 & 2.020 \\
\hline
\end{tabular}

Table 4. Variation in structural parameters of woody vegetation in parks by municipality and district.

\begin{tabular}{|c|c|c|c|c|c|c|}
\hline & & $\begin{array}{c}\text { Density } \\
\text { (individuals/ha) }\end{array}$ & $\begin{array}{c}\text { Canopy } \\
\text { cover } \\
(\%)\end{array}$ & $\begin{array}{c}\text { Basal } \\
\text { area } \\
\left(\mathrm{m}^{2} / \mathrm{ha}\right)\end{array}$ & $\begin{array}{c}\text { Shannon } \\
\text { Diversity } \\
\text { Index } \\
\text { (bits) }\end{array}$ & $\begin{array}{l}\text { Pielou } \\
\text { regularity } \\
\text { Index }\end{array}$ \\
\hline \multirow{4}{*}{$\begin{array}{l}\text { Municipalities } \\
\text { and district }\end{array}$} & Djinaky & 19.2 & 28.49 & 5.48 & 3.38 & 0.77 \\
\hline & Kataba 1 & 64 & 25.38 & 3.02 & 3.19 & 0.61 \\
\hline & Kafountine & 55.31 & 13.10 & 2.82 & 2.74 & 0.53 \\
\hline & Arr Katabal & 56.12 & 27.9 & 5.9 & 3.18 & 0.55 \\
\hline
\end{tabular}

Kataba1 district is relatively high at $84.17 \%$. This rate is higher in the parks of the municipality of Djinaky (86.93\%), followed by the municipality of Kataba1 $(84.64 \%)$. The lowest regeneration rate is noted in the parks of the municipality of Kafountine with $83.78 \%$.

\subsection{Woody Vegetation Structure of Parks}

\subsubsection{Vertical Structure}

The vertical structure of the woody vegetation in the agroforestry parks of the Kataba district 1 is L-shaped. This structure is characteristic of a young stand indeed, individuals belonging to the height class [2 - $4 \mathrm{~m}$ [ are the most 
represented (48.07\%). Individuals with a height greater than $20 \mathrm{~m}$ are poorly represented with $0.92 \%$ of the stand (Figure 3 ).

Katabal and Kafountine municipalities have vertical " $L$ " structures characteristic of a young stand with a predominance of individuals between 2 and $4 \mathrm{~m}$ in height. This height class includes 49.34 and $48.4 \%$ of the individuals in the stand in Kafountine and Kataba1 municipalities respectively. Individuals with a height greater than $20 \mathrm{~m}$ are very poorly represented with $0.59 \%$ and $11 \%$ in Kafountine and Kataba1 municipalities respectively. In the district of Djinaky, individuals with a height of between 14 and $16 \mathrm{~m}$ are the most represented (39.13\%). Individuals in the [2 $-4 \mathrm{~m}[,[6-8 \mathrm{~m}$ [ and [12 - $14 \mathrm{~m}$ [ height classes are poorly represented with $4.35 \%$ of individuals each (Figure 3 ).

\subsubsection{Horizontal Structure}

In the agroforestry parks of the district, individuals with a diameter between 5 and $20 \mathrm{~cm}$ are the most represented (39.19\%). This class is followed by the one with a diameter between 20 and $35 \mathrm{~cm}$ (36.60\%). Individuals with a diameter > $110 \mathrm{~cm}$ are the least represented with only $0.49 \%$ of the individuals in the stand (Figure 4).

In the parks of the minicipality of Djinaky, we note a dominance of individuals in the [25-45 cm [ class (34.78\%). The least represented individuals are those with diameters between 95 and $110 \mathrm{~cm}$ and those with diameters greater than $110 \mathrm{~cm}$. These classes each contain $4.35 \%$ of the individuals in the stand.
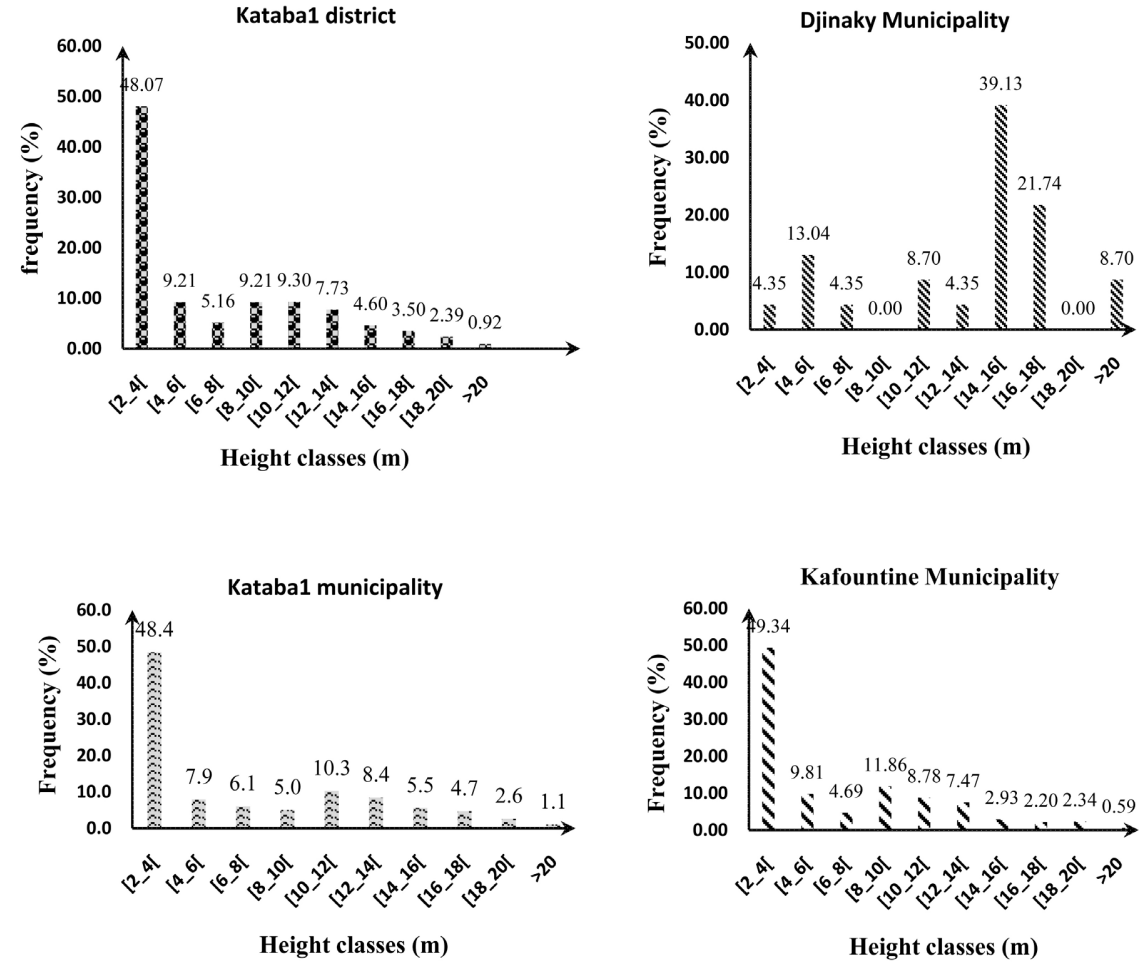

Figure 3. Distribution of individuals in the woody stand of agroforestry parks by height classes according to the municipalities and Katabal district. 

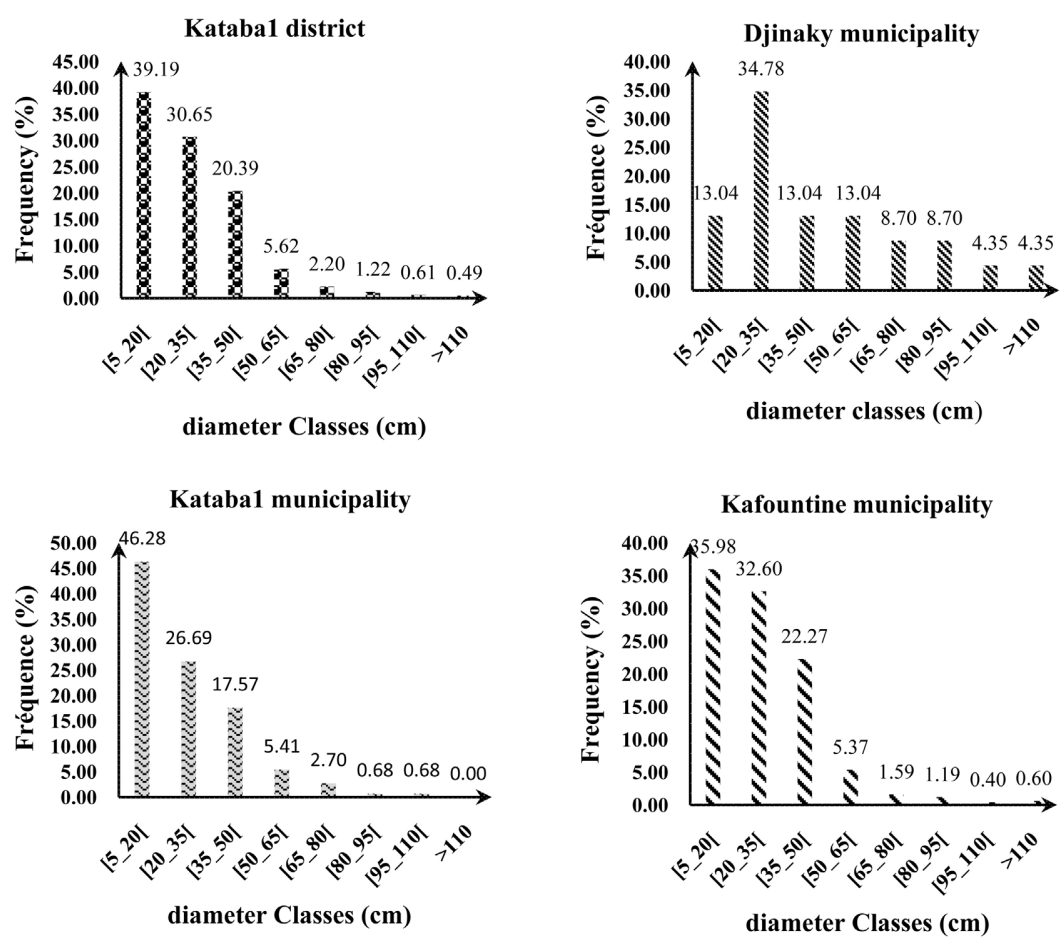

Figure 4. Distribution of individuals in the woody stand of agroforestry parks by diameter classes according to the municipalities and Katabal district.

As for the parks in the Katabal municipality, they are characterized by a predominance of individuals with diameters between 5 and $20 \mathrm{~cm}$ with $48.28 \%$ of the individuals. On the other hand, individuals belonging to the [80 - 95 $\mathrm{cm}$ [ and [95-110 $\mathrm{cm}$ [ diameter classes are the least represented with $0.68 \%$ for each of the classes.

The structure of the woody stand in the parks of the municipality of Kafountine reveals a predominance of individuals in the $[5-20 \mathrm{~cm}$ [ diameter class with $35.98 \%$ of individuals. Individuals with diameters between 95 and $110 \mathrm{~cm}$ are the least represented $(0.40 \%)$.

\subsection{Typology of the Parks According to the Municipalities}

It appears from the analysis of the figure below that the F1 and F2 axes explain $100 \%$ of the variation in the parameters studied. The Principal Component Analysis (PCA) allowed us to distinguish two major groups of parks based on the floristic and structural characteristics of the woody vegetation:

Group A agroforestry parks, found in the municipality of Djinaky, characterized by high cover, basal area and diversity;

Group B agroforestry parks, located on the negative abscissa side, are made up of two subgroups. Subgroup B1 represents the parks of the Kataba1 municipality, characterized by a high density, specific richness and regeneration rate but with a low basal area. The B2 subgroup represents the parks of the municipality of Kafountine, which are characterized by a low cover rate and low specific diversity (Figure 5). 


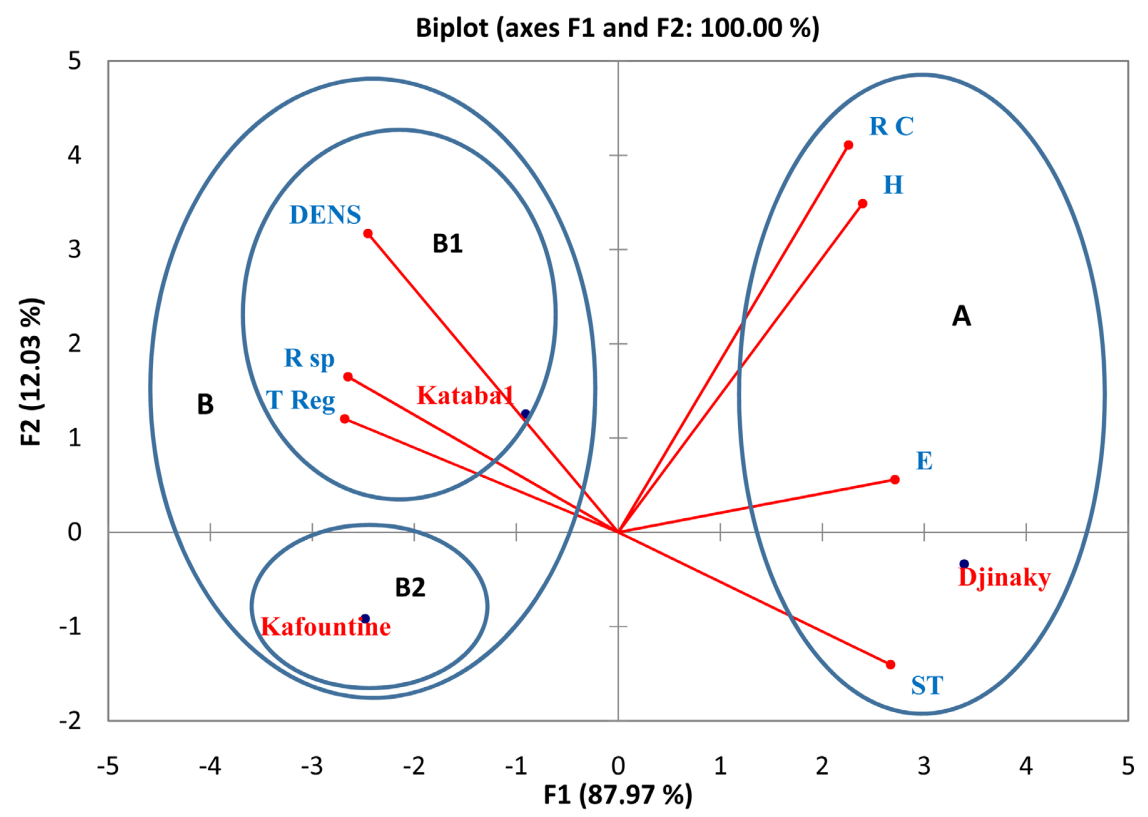

Figure 5. Characteristics of agroforestry parks in the Kataba 1 district. Legend: $\mathrm{T} \mathrm{R}=\mathrm{ca}$ nopy cover; Dens = density; $\mathrm{S} \mathrm{T}=$ basal area; $\mathrm{T}$ Reg = regeneration rate; rich $\mathrm{sp}=$ species richness.

\section{Discussion}

The objective of this study was to characterize the woody vegetation of the agroforestry parks in the Katabal district. The study showed that the flora of the parks in the Katabal district is rich in seventy-five (73) species divided into fifty-five (55) genera and twenty-eight (27) botanical families. The most represented family is the Fabaceae. These results are close to those of [16] who found 54 species, 43 genera and 24 families at the level of agroforestry parks in the island terroir of Mar Fafaco, Senegal. They are different from [17] who inventoried seven (7) plant species in the city of Nukus. Agroforestry parks in the Katabal district are very diverse with a Shannon index $(\mathrm{H})$ equal to 3.18 bits. This result is close to that of [10] who found at the level of agroforestry parks with Elaeis guineensis in Lower Casamance, Shannon indices of 3.27 bits, 4.12 bits and 2.92 bits respectively in Carounate, Kabiline and Kaguitte.

The most frequent woody species in the agroforestry parks of the katabal district are Borassus akeassii (42.42\%), Mangifera indica (40.40\%), and Citrus sinensis $(39.39 \%)$. The predominance of these species can be explained by the fact that in this area, orange and mango orchards are used as crop fields by farmers at the same time. These results are consistent with those of [18] who state that some species are maintained in the fields by farmers for socioeconomic reasons.

The results for the cover rate $(27.9 \%)$, basal area $\left(5.9 \mathrm{~m}^{2} / \mathrm{ha}\right)$ and density (56.12 ind/ha) are different from those of [19] who found a basal area equal to $10.57 \mathrm{~m}^{2} / \mathrm{ha}$ and a density of $169.4 \mathrm{stems} / \mathrm{ha}$ in natural formations in the Sudanian zone in Benin. This difference could be explained for pedoclimatic reasons. 
These results are also different from those of [20] Yameogo et al. who recorded a density 8.25 individuals/ha in Vipalogo agroforestry parks in Burkina Faso in 2014.

The regeneration rate of woody vegetation in the agroforestry parks of Kataba1 district is relatively high at $84.17 \%$. These results are close to those of [21], who found a rate of $88.19 \%$ in the woody stands of the agroforestry parks in Tendouck district. This can be explained according to [22] by the protection and maintenance of certain woody species in the fields and particularly those with socio-economic interest. These results are different from those recorded by [23] Diatta et al. who found a regeneration of 1 individual/ha at Keur Samba DIA in the groundnut basin.

The demographic structure of the woody vegetation in the agroforestry parks of the Katabal district is characteristic of a young and balanced stand with a predominance of individuals with a height of between 2 and $4 \mathrm{~m}$ and a diameter of between 5 and $20 \mathrm{~cm}$. This could be explained by the high regeneration capacity of woody vegetation in the parks and the good level of recruitment of young individuals to the intermediate classes. These results are consistent with those of [24] who conducted their study in the groundnut basin of Senegal, in the regions of Kaolack and Fatick. They are also in line with those of [25] who worked on the structure and dynamics of the flora and vegetation of the Noflaye Special Botanical Reserve.

\section{Conclusions}

The objective of the study was to characterize the woody vegetation of the agroforestry parks of the Katabal district. A total of seventy-five (73) species divided into fifty-five (55) genera and twenty-eight (27) families were inventoried, with a predominance of the Fabaceae family in the agroforestry parks of the Katabal district. The density, cover rate, basal area and regeneration rate are 56.12 individuals/ha, $27.9 \%, 5.9 \mathrm{~m}^{2} /$ ha and $84.17 \%$ respectively. The demographic structure of the woody stand is characteristic of a young and balanced stand with a predominance of individuals of height between 2 and $4 \mathrm{~m}$ (48.07\%) and diameter between 5 and $20 \mathrm{~cm}$ (39.19\%).

It seems appropriate to continue this study in the other departments of the Lower Casamance in order to have a database for more rational and sustainable management of the parks.

\section{Acknowledgements}

The authors would like to thank the farmers for their hospitality and support in the field, as well as Mr Jean BASSENE for his help in drawing up the location map of the study area.

\section{Conflicts of Interest}

The authors declare no conflicts of interest regarding the publication of this paper. 


\section{References}

[1] Boffa, J.-M. (2000) Les parcs agroforestiers en Afrique de l'Ouest: clés de la détermination et de la gestion durable. Unasylva 200, 51, 11-17.

[2] Pullan, R.A. (1974) Farmed Parkland in West Africa. Savanna, 3, 119-151.

[3] Raison, J.-P. (1988) Les parcs en Afrique: État des connaissances, perspectives de recherches Document de travail Centre d'études africaines. EHESS (École des hautes études en sciences sociales), Paris, $117 \mathrm{p}$.

[4] Anonyme (1992) Plan d'Action Forestier du Sénégal. Vol I, Ministère du développement rural et de l'hydraulique, Dakar, Sénégal, $332 \mathrm{p}$.

[5] Food and Agriculture Organization of the United Nations (1995) Non-Wood Forest Products for Rural Income and Sustainable Forestry. Non-Wood Forest Products Paper No. 7, Food and Agriculture Organization of the United Nations, Rome, 127 p.

[6] Ganaba, S. (1996) A propos du neem au Burkina Faso: Nécessité d'une maîtrise de son expansion. Science et technique (CNRST, Burkina Faso), 22, 66-74.

[7] Nacoulma, B.M.I. (2012) Dynamique et stratégie de conservation de la végétation et de la phytodiversité du complexe écologique du Parc National du W du Burkina Faso. Thèse de doctorat, Université de Ouagadougou, Burkina Faso, 151 p.

[8] Sagna, P. (2005) Dynamique du Climat et son évolution récente dans la partie Ouest de l'afrique occidentale. Thèse de Doctorat, Université Cheikh Anta Diop de Dakar, $786 \mathrm{p}$.

[9] Coly, I., Badji, A., Ngom, D., Goudiaby, A.O.K. and Drame, M. (2020) A Structure and Diversity of Agroforestry Parks in the Tenghory District (Lower Casamance, Senegal). American Journal of Agriculture and Forestry, 8, 198-207.

https://doi.org/10.11648/j.ajaf.20200805.13

[10] Ngom, D., Camara, B., Gomis, Z.D. and Sagna, B. (2018) Cortège floristique, paramètres structuraux et indicateurs d'anthropisation des parcs agroforestiers à Elaeis guineensis Jacq en Basse Casamance, Sénégal. Journal of Animal and Plant Sciences, 36, 5919-5932.

[11] Gueye, S. (2008) Plan d'aménagement et de gestion sylvo-pastoral de la forêt classée des kalounayes version finale juin 2008. 98 p.

[12] Thiombiano, A., GleleKakaï, R., Bayen, P., Boussim, J.I. and Mahamane, A. (2016) Méthodes et dispositifs d'inventaires forestiers en Afrique de l'ouest: état des lieux et propositions pour une harmonisation. Annales des Sciences Agronomiques 20, spécial Projet Undesert-UE, 15-31.

[13] Ramade, F. (2003) Éléments d'Écologie: Écologie fondamentale. 3ème édition, Dunod, Paris, $690 \mathrm{p}$.

[14] Shannon, C.E. and Weaver, W. (1949) The Mathematical Theory of Communication. University of Illinois Press, Urbana.

[15] Devineau, J.L. (1999) Seasonal Rhythms and Phonological Plasticity of Savannah Woody Species in a Follow Farming System (Southwest Burkina Faso). Journal of Tropical Ecology, 15, 497-513. https://doi.org/10.1017/S0266467499000978

[16] Diedhiou, M.A.A., Faye, E., Ngom, D. and Toure, M.A. (2014) Identification et caractérisation floristiques des parcs agroforestiers du terroir insulaire de Mar Fafaco (Fatick, Sénégal). Journal of Applied Biosciences, 79, 6855-6866. https://doi.org/10.4314/jab.v79i1.11

[17] Kurbaniyazov, B.T. (2020) Analysis of the State of Woody Plants in the City of Nukus (Streets of Ernazar Alakoz). American Journal of Plant Sciences, 11, 896-902. https://doi.org/10.4236/ajps.2020.116065 
[18] Sene, A. (1994) Etude socio-économique des systèmes à parc dans le bassin arachidier: Cas de Sterculia setigera et Cordyla pinnata: "Mémoire de confirmation: Direction des Recherches sur les Productions Forestières, Bambey (Sénégal), 94 p.

[19] Kakaï, R.L.G., Sinsin, B. and Palm, R. (2008) Etude dendrométrique de Pterocarpus erinaceus Poir des formations naturelles de la zone soudanienne au Bénin Agronomie Africaine, $12 \mathrm{p}$.

[20] Yameogo, G., Ouedraogo, H. and Yelemou, B. (2019). Dynamique de la biodiversité des parcs agroforestiers de Vipalogo en zone nord soudanienne du Burkina Faso. International Journal of Biological and Chemical Sciences, 13, 2765-2776. https://doi.org/10.4314/ijbcs.v13i6.27

[21] Coly, I., Diatta, T.C., Ngom, D., Badji, A. and Gueye, O. (2020) Caractéristiques de la flore et de la végétation ligneuses des parcs agroforestiers de l'arrondissement de Tendouck (Basse Casamance, Sénégal). International Journal of Biological and Chemical Sciences, 14, 1558-1575. https://doi.org/10.4314/ijbcs.v14i5.6

[22] Morou, B., Ounani, H., Oumani, A.B., Diouf, A., Guero, G. and Mahamane, A. (2016) Caractérisation de la structure démographique des ligneux dans les parcs agroforestiers du terroir de Dan Saga (Aguié, Niger). International Tournal of Biological and Chemical Sciences, 10, 1295-1311.

https://doi.org/10.4314/ijbcs.v10i3.31

[23] Diatta, A.A., Ndour, N., Manga, A., Sambou, B., Faye, C.S., Diatta, L. and Mbow C. (2016) Composition floristique et dynamique du parc agroforestier à Cordyla pinnata (Lepr. ex A. Rich.) Milne-Redh. dans le Sud du Bassin Arachidier (Sénégal). International Journal of Biological and Chemical Sciences, 10, 1805-1822. https://doi.org/10.4314/ijbcs.v10i4.29

[24] Charahabil, M.M., Lo, M., Bassène, E. And Akpo, L.E. (2008) Caractéristiques de la flore et Végétation ligneuses de forêts communautaires de la zone soudano-sahélienne au Sénégal. Journal des Sciences et Technologies, 6, 72-85.

[25] Diouf, J., Mbaye, M.S., Camara, A.A., Dieng, B., Diouf, N., Sarr, M. And Noba, K. (2019) Structure et dynamique de la flore et la végétation de la réserve spéciale botanique de Noflaye (Sénégal). International Journal of Biological and Chemical Sciences, 13, 14-58. https://doi.org/10.4314/ijbcs.v13i3.20 